\title{
Heteroptera Coreidae (Anoplocnemis curvipes, Homoeocerus pallens, Leptoglossus membranaceus et Pseudotheraptus devastans) : Four crop pest and their wild host plants
}

\author{
YEBOUE N'Guessan Lucie ${ }^{1 *}$, SORO Senan ${ }^{12}$, TRA BI Crolaud Sylvain ${ }^{1}$ \\ ${ }^{1}$ Université Jean Lorougnon Guédé, UFR Agroforesterie et UFR Environnement, BP 150 Daloa, Côte d'Ivoire \\ ${ }^{2}$ Centre Suisse de Recherches Scientifiques en Côte d'Ivoire
}

\begin{abstract}
Heteroptera Coreidae are all phytophagous insects. They are both meet on cultivated and wild plants. The objective of this study was to identify the Coreinae on the different crops grown in Côte d'Ivoire, evaluate the damage on these plants and identify wild plants that serve as their refuge in the absence of crops. The samplings were carried out in areas cultivated across different regions and in the reserve of Lamto. The insects were captured using a sweep net, a harvesting cage and threshing technics. The catching were once a week in different areas during one year. The results indicate that among Coreinae harvested, Anoplocnemis curvipes, Homoeocerus pallens, Leptoglossus membranaceus and Pseudotheraptus devastans were the mostly encountered on the prospected plants. The polyphagous species was A. curvipes with over than 60 host plants identified. Gossypium barbadense was the most infected by the Coreinae, followed by Cocos nucifera and Vigna unguiculata. The damage caused by these insects on the plants and the yields are function of their number in the field.
\end{abstract}

Keywords: Heteroptera, Coreinae, pests, Côte d'Ivoire

\section{INTRODUCTION}

Heteroptera family contain a great number of tropical species (Chaudonneret 1990). They are divided into more than 70 families (Capsidae Miridae, Coreidae, Lygeidae, Pentatomidae, Pyrrochoridae, Tingidae, etc.). More than 75,000 species have been described worldwide (Leraut, 2003). The Coreidae are a cosmopolitan family found in all zoogeographic regions. There are crop pests. According to Appert and Deuse (1988), the damage caused by piercing-sucking can be summarized in mechanical action, toxic and infectious diseases inoculated. They transmit by their bites, pathogens (fungi, bacteria and viruses), which cause sometimes serious diseases.

The intensity of damage caused by these insects is linked to their number on the field. Thus, in West Africa, several species of Coreidae (Anoplocnemis spp., Clavigralla tomentosicollis STÅL, Mirperus jaculus THUNB, Riptortus $s p$.) attack the pods and seeds which reduce significantly the yield from 10 to $80 \%$ (Seri-Kouassi, 2004). According to Mariau et al., (1981), the damage caused by Pseudotheraptus devastans (coconut devastating bug) may decrease production between 50 to $80 \%$ in West Africa. In America, Dupont and Dennill (1996) estimate the losses due to Pseudotheraptus Wayi BROWN at about 1400000 to 600,000 \$. Several methods of struggle against these insects are conducted in the field (Tano, 2007; Abdul Habu, 2014).

All these data show that these insects are formidable plants pests. The objective of this study was to identify coreinae on the different types of crops grown, estimate their damage and identify wild plants that serve as their refuge in the absence of crop plants.

\section{STUDY ZONE}

The rainfall regime in Côte d'Ivoire is linked to the movements of the Intertropical Front Transition (FIT) that distinguishes four types of climate (Berron, 1971).

In the south, the climate is sub-equatorial characterized by two rainy seasons (March to July and October to November) and two dry seasons (December to February and August to September). Annual rainfall varies between $1400 \mathrm{~mm}$ to $2500 \mathrm{~mm}$. The mean temperature varied from 26 to $27^{\circ}$ C.The central region characterized by the equatorial transitional climate receives an annual rainfall between 850 to $1700 \mathrm{~mm}$ concentrated during the rainy

${ }^{1}$ Corresponding Author: yebouelucile@yahoo.fr 


\section{American Research Journal of Agriculture, Volume 1, Issue 4, 2015}

ISSN 2378-9018

season, from March to June and September to October. The dry season runs from November to February. The mean of annual temperatures varied between 26 to $27^{\circ} \mathrm{C}$.

The North is characterized by the Sudanese climate which has a rainy season from April to September and a dry season from October to March. Annual rainfall varies between 600 to $1030 \mathrm{~mm}$ and annual temperatures varies from 30 to $31^{\circ} \mathrm{C}$.

In the west: the mountain climate is characterized by a rainy season from March to October with intense rains from July to September and a dry season from November to February. The mean of rainfall varies from 1400 to $1600 \mathrm{~mm}$ in the northwest and from 1500 to $1900 \mathrm{~mm}$ in the west. The mean of annual temperature is around $24^{\circ} \mathrm{C}$ in the west and between 25 and $27^{\circ} \mathrm{C}$ in the northwest. The relative humidity is very high, at about $98 \%$ (Koli and Brou, 1996).

\section{MATERIEL AND METHODS}

The samplings were carried out in different types of plants cultivated and representative of prospected areas. Farmer's field, experimental fields and the naturel reserve of Lamto were concerned. Insects were captured with a sweep net, harvest cage and the threshing technics. The samplings were made once a week in different areas. A total of 52 passages were performed at all sites. The net catches were carried out on $100 \mathrm{~m}^{2}$ randomize surfaces. Biocenometer Harvested cages hugged of $1 \mathrm{~m}^{3}$ were putted on the ground previously chosen by random for insects trapping. To access the interior of the harvesting cage, a pocket was made bellow.

Harvesting by beating was used to collect insects that were in the bushes. It was consisted in extending on the floor preferably choose a white cloth and tap the shrub vigorously to sample. Insects that were hiding there, fall down themselves on the white cloth. The insects collected are temporarily stored in bottles containing cotton soaked in ether. Plants on which these insects were captured are collected to form a herbarium for identification.

At each harvest, the date, the site and the type of vegetation were mentioned. Once in the laboratory, these insects are counted, identified and put either in bottles containing alcohol at $70^{\circ} \mathrm{C}$; or in collection boxes after their passage through the oven at $45^{\circ} \mathrm{C}$. For the estimation of damage caused on plants, the Code established by WEBER FECHENER has been used:

0: no symptoms;

$1: \leq 5 \%$ of the part of the plant concerned were destroyed;

2: 5 to $25 \%$ of the part of the plant concerned were destroyed;

3: 25 to $50 \%$ of the part of the plant concerned were destroyed;

4: $\geq 50 \%$ of the part of the plant concerned were destroyed.

These measurements were taken on ten plants per plant species in each plot. The data were collected on leaves, stems, flowers and fruits.

\section{RESULTS}

\subsection{Host Plants}

Anoplocnemis curvipes, Homoeocerus pallens, Leptoglossus membranaceus and Pseudotheraptus devastans species were respectively found on 65, 23, 16 and 7 host plants (table I). the cultivated host plants sampling were : Anacardium occidentalis, Mangifera indica (Anacardiaceae); Cocos nucifera, Elaeis guineensis (Arecaceae); Ipomoea batatas (Convolvulaceae); Cucumus sativus, Cucurbita maxima, Langenaria vulgaris (Cucurbitaceae); Hevea brasiliensis, Manihot esculenta (Euphorbiaceae); Arachis hypogea, Glycine max, Phaseolus lunatus, Vigna unguiculata (Fabaceae); Persea africana (Lauraceae); Abelmoschus esculentus, Gossypium barbadense (Malvaceae); Musa paradisiaca (Musaceae); Psidium guajava (Myrtaceae); Passiflora edulis (Passifloraceae), Oryza glabberima, Zea mays (Poaceae); Coffea arabica (Rubiaceae); Citrus limosus, C. maxima, C. sinensis (Rutaceae); Lycopersicon esculentum, Solanum nodiflorum, S. melongena (Solanaceae) and Theobroma cacao (Sterculiaceae).

The 4 species of coreinae collected were also found on industriel crops such as Theobroma cacao and Coffea arabica. On a total of 72 plants investigated, Anoplocnemis curvipes was the more encountered with more than $90 \%$ of the plants collected. The over species were found less than $50 \%$ time on plants visited. 
American Research Journal of Agriculture, Volume 1, Issue 4, 2015

ISSN 2378-9018

A. curvipes as also been found on cultivated plants and the wild one to. Its presence was remarquable on vegetables one. As Leptoglossus membranaceus concerned, it has been found on Cucurbitaceae such as Cucumus sativus, Cucurbita maxima and Lagenaria vulgaris SER and the Rutaceae (Citrus limosus, Citrus maxima and Citrus sinensis) and also on others plants to (Table I). For Homoeocerus pallens, larvae and adults have been encountered on Albizzia adianthifolia, A. zigia and Acacia ataxacantha (Mimosaceae) in the Forest zone and on Parkia biglobosa (Mimosaceae) in the Savannah one. Pseudotheraptus devastans has been found on the young coconuts trees, Anacardium occidentalis, Manihot esculenta, Theobroma cacao, Coffea arabica and Hevea brasiliensis

Table1. Host plants of the four Coreinae

\begin{tabular}{|c|c|c|c|c|}
\hline Host plants & A. curvipes & H. pallens & L. membranaceus & P. devastans \\
\hline Abelmoschus esculentus & $\mathbf{X}$ & & & \\
\hline Acacia ataxacantha & & $\mathbf{X}$ & & \\
\hline Albizzia adiantifolia & & $\mathbf{X}$ & & \\
\hline Alchornea cordifolia & & $\mathbf{X}$ & & \\
\hline Anacardium occidentalis & $\mathbf{X}$ & $\mathbf{X}$ & & $\mathbf{X}$ \\
\hline Annona senegalensis & & $\mathbf{X}$ & & \\
\hline Arachis hypogea & $\mathbf{X}$ & & & \\
\hline Aspilia africana & & $\mathbf{X}$ & & \\
\hline Bambusa vulgaris & $\mathbf{X}$ & & & \\
\hline Bidens pilosa & $\mathbf{X}$ & & & \\
\hline Cassia tora & $\mathbf{X}$ & & & \\
\hline Chromolaena odorata & $\mathbf{X}$ & & & \\
\hline Citrus limosus & $\mathbf{X}$ & $\mathbf{X}$ & $\mathbf{X}$ & \\
\hline Citrus maxima & $\mathbf{X}$ & & $\mathbf{X}$ & \\
\hline Citrus sinensis & $\mathbf{X}$ & & $\mathbf{X}$ & \\
\hline Cocos nucifera & & & & $\mathbf{X}$ \\
\hline Coffea arabica & $\mathbf{X}$ & $\mathbf{X}$ & $\mathbf{X}$ & $\mathbf{X}$ \\
\hline Crotalaria juncea & $\mathbf{X}$ & & & \\
\hline Crotalaria lepieurri & & $\mathbf{X}$ & & \\
\hline Crotalaria retusa & $\mathbf{X}$ & & & \\
\hline Cucumus sativus & $\mathbf{X}$ & & $\mathbf{X}$ & \\
\hline Cucurbita maxima & $\mathbf{X}$ & & $\mathbf{X}$ & \\
\hline Daniella oliveri & $\mathbf{X}$ & & & \\
\hline Desmodium velutinum & $\mathbf{X}$ & & & \\
\hline Dioscorea alata & $\mathbf{X}$ & & & \\
\hline Emilia praetermissa & $\mathbf{X}$ & & & \\
\hline Erigeron floribundus & $\mathbf{X}$ & & & \\
\hline Eriosema griseum & $\mathbf{X}$ & & & \\
\hline Eriosema molle & $\mathbf{X}$ & & & \\
\hline Erythrina indica & $\mathbf{X}$ & & & \\
\hline Fagara macrophylla & & & $\mathbf{X}$ & \\
\hline Fagara rubescens & $\mathbf{X}$ & & $\mathbf{X}$ & \\
\hline Ficus capensis & & $\mathbf{X}$ & & \\
\hline Glycine $\max$ & $\mathbf{X}$ & & & \\
\hline Gossypium barbadense & $\mathbf{X}$ & $\mathbf{X}$ & & \\
\hline Hevea brasiliensis & $\mathbf{X}$ & & & $\mathbf{X}$ \\
\hline Hibiscus sabdarriffa & $\mathbf{X}$ & & & \\
\hline Indigofera hirsuta & $\mathbf{X}$ & & & \\
\hline Indigofera polysphaera & $\mathbf{X}$ & & & \\
\hline Ipomoea batatas & $\mathbf{X}$ & & $\mathbf{X}$ & \\
\hline Langenaria vulgaris & $\mathbf{X}$ & & $\mathbf{X}$ & \\
\hline Lycopersicon esculentum & $\mathbf{X}$ & & $\mathbf{X}$ & \\
\hline Mangifera indica & $\mathbf{X}$ & & & \\
\hline Manihot esculenta & $\mathbf{X}$ & $\mathbf{X}$ & & $\mathbf{X}$ \\
\hline
\end{tabular}


American Research Journal of Agriculture, Volume 1, Issue 4, 2015

ISSN 2378-9018

\begin{tabular}{|c|c|c|c|c|}
\hline Musa paradisiaca & & & $\mathbf{X}$ & \\
\hline Nauclea latifolia & & $\mathbf{X}$ & & \\
\hline Oryza glabberima & $\mathbf{X}$ & $\mathbf{X}$ & & \\
\hline Panicum milaceum & $\mathbf{X}$ & $\mathbf{X}$ & & \\
\hline Parkia biglobosa & & $\mathbf{X}$ & & \\
\hline Pennisetum spicatum & $\mathbf{X}$ & $\mathbf{X}$ & & \\
\hline Pennisetum typhoides & $\mathbf{X}$ & $\mathbf{X}$ & & \\
\hline Persea americana & $\mathbf{X}$ & & & \\
\hline Petersianthus macrocarpus & $\mathbf{X}$ & & & \\
\hline Phaseolus lunatus & $\mathbf{X}$ & & & \\
\hline Phyllanthus amarus & $\mathbf{X}$ & & & \\
\hline Phyllanthus mullerianus & $\mathbf{X}$ & & & \\
\hline Physalis angulata & $\mathbf{X}$ & & & \\
\hline Piliostigma thonningii & $\mathbf{X}$ & $\mathbf{X}$ & & \\
\hline Psidium guajava & $\mathbf{X}$ & & $\mathbf{X}$ & \\
\hline Rosa canina & & & & $\mathbf{X}$ \\
\hline Rosa sinensis & $\mathbf{X}$ & & & \\
\hline Sesamum indicum & $\mathbf{X}$ & & $\mathbf{X}$ & \\
\hline Sida rhombifolia & & $\mathbf{X}$ & & \\
\hline Solanum melongena & $\mathbf{X}$ & & $\mathbf{X}$ & \\
\hline Stachytarpheta cayennensis & & $\mathbf{X}$ & & \\
\hline Tephrosia bracteolata & $\mathbf{X}$ & & & \\
\hline Tephrosia vogiliana & & $\mathbf{X}$ & & \\
\hline Theobroma cacao & $\mathbf{X}$ & $\mathbf{X}$ & $\mathbf{X}$ & $\mathbf{X}$ \\
\hline Vernonia conferta & & $\mathbf{X}$ & & \\
\hline Vigna unguiculata & $\mathbf{X}$ & & & \\
\hline Zea mays & $\mathbf{X}$ & & & \\
\hline Zinia elegans & $\mathbf{X}$ & & & \\
\hline TOTAL & 65 & 25 & 16 & 7 \\
\hline
\end{tabular}

4.2. Damage

The table 2 shows that coreinae have a negative impact on the productivity of their host plants. However, the effects of damage on Gossypium barbadense were the most important. This plant seem to be the most attack by the coreinae. It is followed by the vegetable plants and then some plants such as Cocos nucifera and Vigna unguiculata. Indeed, on these plants the impact 3, 2 and 1 were respectively observed. For the plants on which the damage 3 has been observed means that the rate of damage caused by coreinae were between 25 and $50 \%$. It is the same for plants for which the index 1 and 2 were observed, it means that less than $25 \%$ of these plants had theirs organs destroyed.

However on other host plants, coreinae are always link to a part of the host plant which is use for their meal. The index of damage on plants shows that all cultivated host plants suffer from the damage caused by these insects. However, woody species plants are less attacked than non-timber one (vegetables). For wood, the damage is greater when plants are very young. The damages are materializing into the wilt when insects feed on the young crop plants or falling bodies when the number of insects is very high on olds plants. On fruit, they are covered with fungi spots after the bites of insects.

Specifically, Anoplocnemis curvipes attacks groundnuts and cotton on which it lives and bites the capsules, the twigs and shoots. It also suck the water (index 3). It damages, particularly, the apical stem which can dry after being bites. On citrus, larvae and adults suck the water by pricking the petiole of the leaves, young stems and occasionally fruit. When the young stems and leaves are attacked, they became black and fall down completely. On Malvaceae, $A$. curvipes attacks the leaves and stems and causing the wilt of the plants (Figure 1).

Homoeocerus pallens larvae and adults growth on young stems and leave by sucking the sap of Mimosaceae. They are also encountered on banana (Figure 2), coffee, rice and cocoa. Leptoglossus membranaceus: its damage are similar to those of Anoplocnemis curvipes on citrus and Cucurbitaceae (Figure 3). 
American Research Journal of Agriculture, Volume 1, Issue 4, 2015

ISSN 2378-9018

Pseudotheraptus devastans: on cocoa pods, larvae and adults cause canker through their bites (index 2). On rubber tree and cassava it attacks the ends of the stems and petioles of young leaves. On these plants, they cause extensive necrotic lesions that can be used by others pathogens and occur frequently others very serious diseases. On coconut, larvae and young adults bite nuts on the outskirts of floral parts and occur the drying of the affected tissue. A single walnut may be face with more species attacks. Areas of pinholes form one or more characteristics crowns. These attacks can result in the interruption of development or decline in young immature nuts (Figure 4).

Table2. Damage index on cultivated host plants

\begin{tabular}{|l|l|l|l|l|l|}
\hline Species & leaves & Boughs & flowers & Fruit & Stem \\
\hline Abelmoschuses culentus & $\mathbf{2}$ & $\mathbf{0}$ & $\mathbf{0}$ & $\mathbf{1}$ & $\mathbf{1}$ \\
\hline Anacardium occidentalis & $\mathbf{1}$ & $\mathbf{1}$ & $\mathbf{2}$ & $\mathbf{1}$ & $\mathbf{0}$ \\
\hline Arachis hypogea & $\mathbf{1}$ & $\mathbf{0}$ & $\mathbf{3}$ & $\mathbf{0}$ & $\mathbf{0}$ \\
\hline Citrus limosus & $\mathbf{1}$ & $\mathbf{0}$ & $\mathbf{0}$ & $\mathbf{1}$ & $\mathbf{0}$ \\
\hline Citrus maxima & $\mathbf{1}$ & $\mathbf{0}$ & $\mathbf{0}$ & $\mathbf{1}$ & $\mathbf{0}$ \\
\hline Citrus sinensis & $\mathbf{1}$ & $\mathbf{0}$ & $\mathbf{0}$ & $\mathbf{0}$ & $\mathbf{0}$ \\
\hline Cocos nucifera & $\mathbf{1}$ & $\mathbf{1}$ & $\mathbf{1}$ & $\mathbf{1}$ & $\mathbf{3}$ \\
\hline Coffea arabica & $\mathbf{1}$ & $\mathbf{1}$ & $\mathbf{2}$ & $\mathbf{1}$ & $\mathbf{0}$ \\
\hline Cucumus sativus & $\mathbf{1}$ & $\mathbf{1}$ & $\mathbf{0}$ & $\mathbf{1}$ & $\mathbf{0}$ \\
\hline Cucurbita maxima & $\mathbf{1}$ & $\mathbf{1}$ & $\mathbf{1}$ & $\mathbf{1}$ & $\mathbf{0}$ \\
\hline Dioscorea alata & $\mathbf{2}$ & $\mathbf{0}$ & $\mathbf{0}$ & $\mathbf{0}$ & $\mathbf{1}$ \\
\hline Elaeis guineensis & $\mathbf{1}$ & $\mathbf{0}$ & $\mathbf{1}$ & $\mathbf{1}$ & $\mathbf{0}$ \\
\hline Glycine max & $\mathbf{2}$ & $\mathbf{1}$ & $\mathbf{1}$ & $\mathbf{1}$ & $\mathbf{1}$ \\
\hline Gossypium barbadense & $\mathbf{2}$ & $\mathbf{2}$ & $\mathbf{2}$ & $\mathbf{3}$ & $\mathbf{1}$ \\
\hline Hevea brasiliensis & $\mathbf{1}$ & $\mathbf{0}$ & $\mathbf{0}$ & $\mathbf{0}$ & $\mathbf{0}$ \\
\hline Hibiscus sabdarriffa & $\mathbf{2}$ & $\mathbf{1}$ & $\mathbf{1}$ & $\mathbf{1}$ & $\mathbf{1}$ \\
\hline Ipomoea batatas & $\mathbf{2}$ & $\mathbf{0}$ & $\mathbf{0}$ & $\mathbf{0}$ & $\mathbf{1}$ \\
\hline Langenaria vulgaris & $\mathbf{2}$ & $\mathbf{1}$ & $\mathbf{2}$ & $\mathbf{2}$ & $\mathbf{1}$ \\
\hline Lycopersicum esculentum & $\mathbf{1}$ & $\mathbf{1}$ & $\mathbf{1}$ & $\mathbf{1}$ & $\mathbf{1}$ \\
\hline Mangifera indica & $\mathbf{1}$ & $\mathbf{0}$ & $\mathbf{1}$ & $\mathbf{1}$ & $\mathbf{0}$ \\
\hline Manihot esculenta & $\mathbf{1}$ & $\mathbf{0}$ & $\mathbf{0}$ & $\mathbf{0}$ & $\mathbf{1}$ \\
\hline Musa paradisiaca & $\mathbf{1}$ & $\mathbf{0}$ & $\mathbf{0}$ & $\mathbf{1}$ & $\mathbf{0}$ \\
\hline Oryza glabberima & $\mathbf{1}$ & $\mathbf{0}$ & $\mathbf{1}$ & $\mathbf{1}$ & $\mathbf{0}$ \\
\hline Passifloraedulis & $\mathbf{1}$ & $\mathbf{0}$ & $\mathbf{1}$ & $\mathbf{1}$ & $\mathbf{0}$ \\
\hline Persea africana & $\mathbf{1}$ & $\mathbf{0}$ & $\mathbf{0}$ & $\mathbf{0}$ & $\mathbf{1}$ \\
\hline Phaseolus lunatus & $\mathbf{1}$ & $\mathbf{1}$ & $\mathbf{1}$ & $\mathbf{2}$ & $\mathbf{1}$ \\
\hline Psidium guajava & $\mathbf{1}$ & $\mathbf{0}$ & $\mathbf{0}$ & $\mathbf{1}$ & $\mathbf{0}$ \\
\hline Solanum nodiflorum & $\mathbf{1}$ & $\mathbf{0}$ & $\mathbf{1}$ & $\mathbf{1}$ & $\mathbf{0}$ \\
\hline Solanum melongena & $\mathbf{1}$ & $\mathbf{0}$ & $\mathbf{2}$ & $\mathbf{1}$ & $\mathbf{0}$ \\
\hline Theobroma cacao & $\mathbf{1}$ & $\mathbf{1}$ & $\mathbf{1}$ & $\mathbf{1}$ & $\mathbf{0}$ \\
\hline Vigna unguiculata & $\mathbf{0}$ & $\mathbf{1}$ & $\mathbf{3}$ & $\mathbf{1}$ \\
\hline Zea mays & $\mathbf{0}$ & $\mathbf{0}$ & $\mathbf{0}$ & $\mathbf{0}$ \\
\hline & & & & \\
\hline & & & & \\
\hline
\end{tabular}

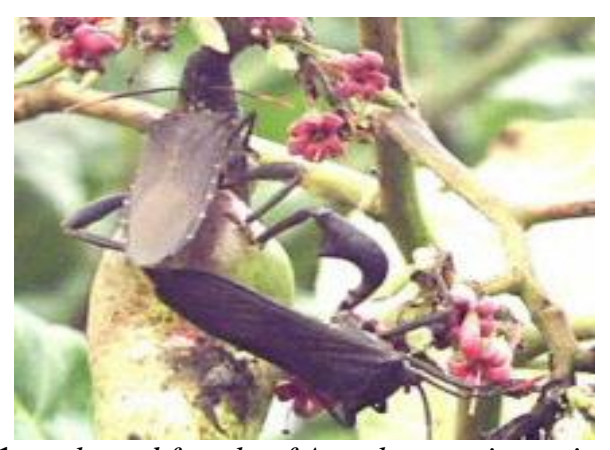

Fig1. male and femele of Anoplocne miscurvipeson Cashew (Dwomohet al, 2008)

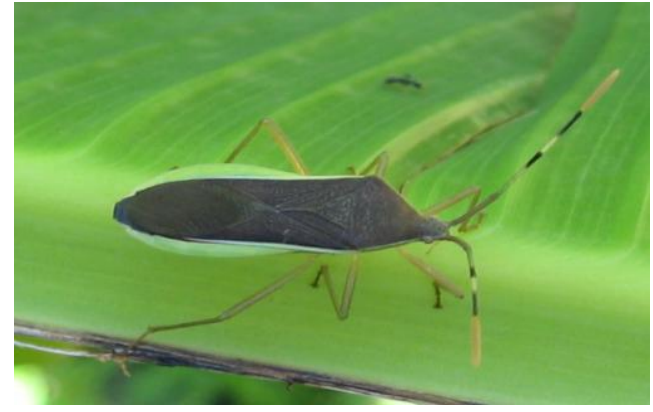

Fig2. Homoeoceruspallens on a bananas leaves 

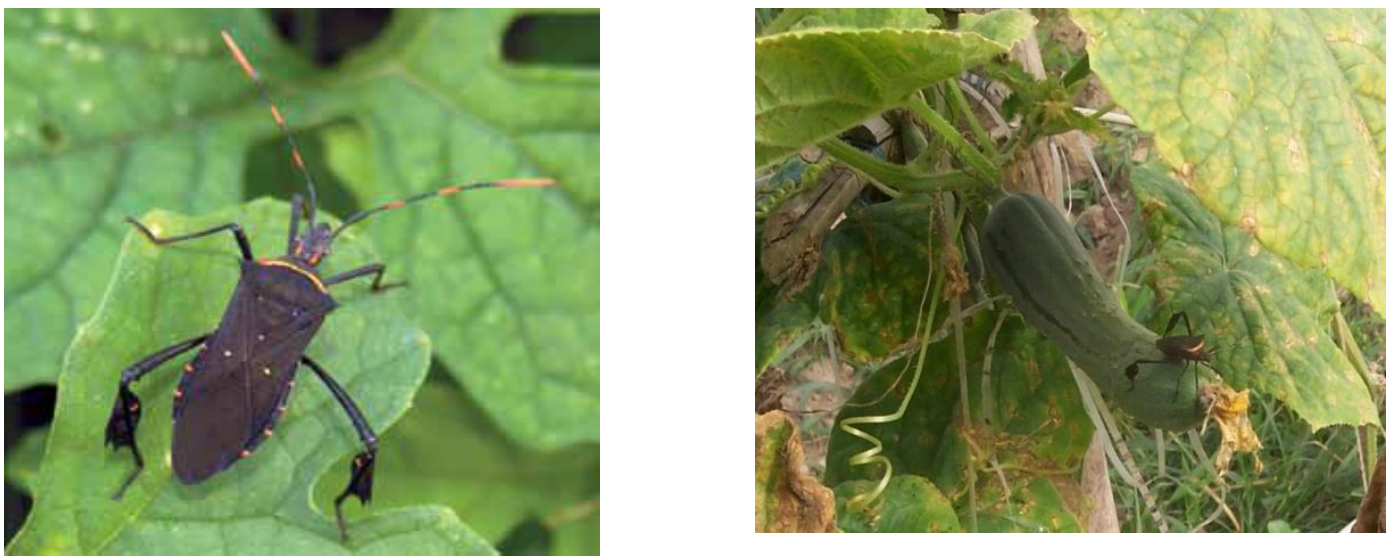

Fig3. Leptoglossusmembranaceuson Cucurbitaceae (leaves and fruit)

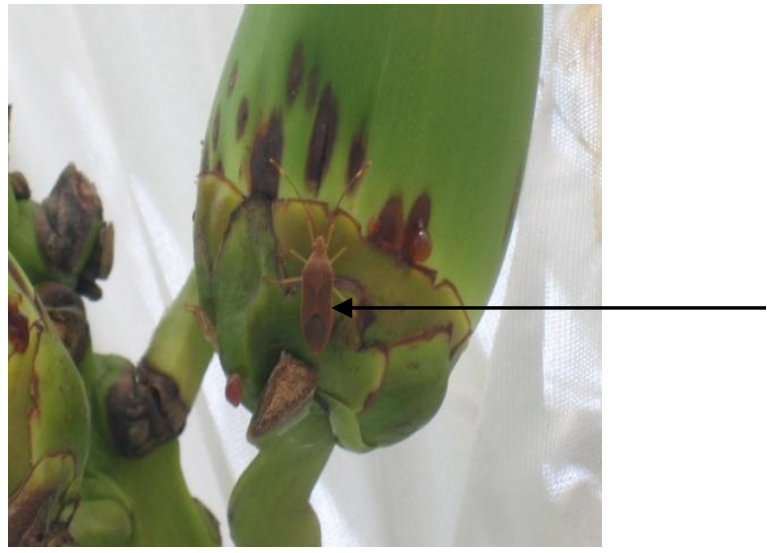

Adult de P. devastans

Fig4. Pseudo theraptus devastanson a coconut (Tano, 2007)

\section{DISCUSSION}

Among the insects captured, Anoplocnemis curvipes totals more than 60 host plants. This indicates that it is a polyphagous insect. This is also observed for the coreinae Amblypelta lutescens REMOTE and Amblypelta nitida STÅL, which feed on a multitude species of plant with respectively 51 and 104 species of host plants in Australia (Mille, 2003). The damage caused by A. curvipes on various plants were reported by Hala (1991) on okra in Bouaké. The damage was also observed on young rubber trees. This insect also feeds on many other wild and cultivated plants. It was also listed on the leaves and twigs of $C$. odorata as reported Gautier (1992) and cashew (Dwomoh et $a l, 2008)$ in Ghana. The damage caused by this insect on the twigs and leaves, prevent the plant to flower in the end of the season when their number is very high. This situation was also noted by Koona et al., (2004), and Soyelu and Akingbohungbe (2006) on cowpea (Vigna unguiculata) in combination with other bugs. These authors report that there is a highly significant correlation between the number of adult bedbugs and damage caused on pods and seeds.

Furthermore, Homoeocerus pallens, Leptoglossus membranaceus and Pseudotheraptus devastans are also polyphagous species. They have no preference for any species or a given plant. They are ubiquitous species which have the advantage to develop throughout any plant during different seasons. This situation explains the high number of these insects in the collection. According to Milles (2003), this scenario is also present in New Caledonia and Vanuatu with the species of Amblypelta bilineata STÅL, which was recognized as a major pest of avocado. According to them, it also attack other plants such as citrus the Annona, mango, macadamia nuts and pepper tree (Schinus terebenthifolius RADDI). Micky et al., (2003) said that these insect were polyphagous species whom are found throughout tropical Africa.

Anoplocnemis curvipes, Homoeocerus pallens, Leptoglossus membranaceus were captured several times on plants of the families of Fabaceae, Mimosaceae, Myrtaceae, Rutaceae and Solanaceae. These same observations have permitted to Schaefer and Mitchell (1983) to say that, there is an association between the Coreidae and their host 


\section{American Research Journal of Agriculture, Volume 1, Issue 4, 2015 ISSN 2378-9018}

plants specially the Mictini with the Fabaceae. The same authors also report that, the most common Coreidae are recorded on these same families of host plants in Australia. Other authors such as Solomon and Froeschner (1981) showed that Coreidae are closely associated with legumes whose stems, pods and seeds are attacked, during the fruiting.

Pseudotheraptus devastans is meet on the young shoots and pods of cocoa. It is also found on the ends of the stems and petioles of the leaves of young rubber trees. On the Pods of cocoa, larvae and adults through their bites cause canker, symptoms which are similar to those produced by Sahlbergella singularis HAGLUND. On rubber, it attacks the ends of the stems and petioles of young leaves, and occur on these organs a hugged necrotic lesions comparable to the damage of Helopeltis sp. This species have been reported by Fokunang et al., (2000) on cassava where it causes damage in association with a fungus (Colletotrichum gloeosporioides). Its damage on the young coconuts destroyed them (Mariau et al., 1981).

\section{CONCLUSION}

The coreinae Anoplocnemis curvipes, Leptoglossus membranaceus, Homoeocerus pallens and Pseudotheraptus devastans were harvested both on food crops (vegetable and industrial) and on wild plants. All these species are polyphagous but Anoplocnemis curvipes has the highest number of host plants. These insects were more found on Citrus plants, the legumes and Cucurbitaceae. The most affected plants are cowpeas, coconut, cucumber, cassava and Malvaceae. The damage observed are multiple and according to their abundance on these plants.

\section{REFERENCES}

[1] Abdoul H. Z., Adam T., Mergeai G., Haubruge E. \& Verheggen F. J., 2014. Effet du mode de conservation de l'huile de Jatropha curcas L. sur son efficacité dans la lutte contre les principaux insectes ravageurs du niébé (Vigna unguiculata (L.) Walp. au Niger. Tropicultura, 32, 4, 191-196

[2] Appert J. \& Deuse J., 1988. Insectes nuisibles aux cultures vivrières et maraîchères (1) et (2). Paris, France : Maisonneuve et Larose. 267 p.

[3] Berron H., 1971. Le climat In : les Atlas Jeune Afrique, les Atlas de Côte d'Ivoire. Paris : 12-14.

[4] Chaudonneret J., 1990. Les pièces buccales des insectes. Thèmes et variations. Ed. hors série du bulletin scientifique de Bourgogne, France : 255 p.

[5] Dwomoh E. A., Ackonor J. B. \& Afun J. V. K., 2008. Survey of insect species associated with cashew (Anacardium occidentale Linn.) and their distribution in Ghana. African Journal of Agricultural Research Vol. 3 (3) : 205-214

[6] Forkunang C. N., Akem C. N., Ikotun T., Dixon A. G. O. \& Tembe E. A. 2000. Role of the Insect Vector, Pseudotheraptus devastans, in Cassava Anthracnose Disease Development. European Journal of Plant Pathology, 106 (4) : 319-327.

[7] Gautier L., 1992. Contact forêt-savane en Côte d'Ivoire Centrale : rôle de Chromolaena odorata (L.) R. King \& H. Robinson dans la dynamique de la végétation. Thèse de Doctorat, Université de Genève, Département de botanique et biologie végétale, Genève, Suisse, 260 p.

[8] Halan N., 1991. Contribution à l'étude de l'entomofaune du gombo (Abelmoschus spp.). Incidence économique. Mémoire de DEA. Université Nationale, Abidjan, Côte d'Ivoire. 41 p.

[9] Koli B. Z. \& Brou Y. T., 1996. Le climat. In : Atlas de l'Ouest de la Côte d'Ivoire Jeune Afrique, Paris : 10-11.

[10] Koona P., Osisanya E. O., Jackai L. \& Tonyer J., 2004. Infestation and damage by Clavigralla tomentosicollis and Anoplocnemis curvipes (Hemiptera: Coreidae) in cowpea plants with modified leaf structure and pods in different positions relative to the canopy. Environ. Entomol., 33 (3) : 471-476.

[11] Leraut P., 2003. Le guide entomologique. Delachaux et Niestlé S A, Lonay, Paris : 527 p.

[12] Mariau D., Desmier D. E., Chenon R., Julia J. F. \& Phillipe R., 1981. Les ravageurs du palmier à huile et du cocotier en Afrique occidentale. Oléagineux ( $\mathrm{N}^{\circ}$ spécial), 36 (4) : 171-213.

[13] Micky D. E., John D. S. \& Robert F. D., 2003. The evolution of omnivory in heteropteran insects. Ecology, 84 : $2549-2556$.

[14] Mille C., 2003. La punaise de l'avocatier (Amblypelta bilineata STÅL). Actualisation des connaissances sur le principal ravageur de l'avocatier. Les cahiers de l'agriculture et de l'environnement, $3: 6-8$.

[15] Mitchell P. L., 2000. Leaf-footed bugs (Coreidae). In Schaefer C.W. \& Panizzi A. C. (eds). Heteroptera of Economic Importance. Boca Raton: 337-403.

[16] Schaefer C. W. \& Mitchell P. L., 1983. Food plants of the Coreoidea (Hemiptera: Heteroptera). Ann. Entomol. Soc. Am., $76: 591-615$.

[17] Seri-Kouassi B. P., 2004. Entomofaune du Niébé (Vigna unguiculata L. WALP) et impact des huiles essentielles extraites de neuf plantes locales sur la reproduction de Callosobruchus maculatus FAB. (Coleoptera Bruchidae) en Côte d'Ivoire. Thèse de Doctorat d'Etat ès-sciences naturelles, UFR Biosciences, Univ. Cocody Abidjan, Côte d'Ivoire, 199 p. 
American Research Journal of Agriculture, Volume 1, Issue 4, 2015

ISSN 2378-9018

[18] Solomon J. C. \& Froeschner R. C. 1981. Notes on food resources and behaviour of the family Coreidae (Hemiptera) in a semi-deciduous tropical forest. Proc. Entomol. Soc. Wash, 428-431.

[19] Soyelu O. L. \& Akingbohungbe A. E., 2006. Histological studies of damage by pod-sucking bugs (Heteroptera: Coreoidea) associated with cowpea Vigna unguiculata ssp. unguiculata in Nigeria. Bull Entomol Res., 96 (4) : 439-44.

[20] Tano D. K. C., 2007. Biologie et incidence des attaques de la punaise Pseudotheraptus devastans Distant (Heteroptera : Coreidae) sur la production de 3 variétés hybrides de cocotier à la station Marc Delorme (Côte d'Ivoire). Mémoire de DEA. Université de Cocody, Abidjan -Côte d'Ivoire, 52 pp. 